\title{
URBAN GROWTH AND ENERGY SUPPLY IN AFRICAN CITIES: THE CASE OF ETHIOPIA
}

\author{
ANDREA HOELTL ${ }^{1}$, ROMAN BRANDTWEINER ${ }^{2}$, TANIA BERGER $^{1} \&$ ROMANA BATES ${ }^{1}$ \\ ${ }^{1}$ Danube University Krems, Austria \\ ${ }^{2}$ Vienna University of Economics and Business, Austria
}

\begin{abstract}
Ethiopia is rapidly urbanising. Similar to other urban areas in developing countries, major issues in Ethiopia include a high level of income inequality, lack of formal employment opportunities and deeply rooted poverty, tenure insecurity, poor infrastructure, and limited access to electricity and energy. Frequently settlers end up in impoverished urban squatters and slums which do not offer them even the most basic infrastructure and hence lack to provide them with the perspectives they came for. Onward migration to farer off destinations such as the EU member states thus often remains as sole option for those caught in such urban poverty traps. Although the issue of informal urban settlements is not new to the context of Ethiopian cities, the current rapid urban growth rates are exposing urban rental markets as well as infrastructure and energy supply to considerable pressure. The paper investigates the respective situation in Ethiopia and demonstrates some best practice examples. In the context of Ethiopian cities, energy production and distribution have been highly centralised under state entities and the scope for exploring local/business driven and decentralised systems has been limited. Transitions can be implemented towards sustainability and the United Nations' Sustainable Development Goals if collective identification and structuring of issues along with collective envisioning of future is provoked or facilitated.
\end{abstract}

Keywords: Ethiopia, informal settlements, energy supply, Paris Agreement, renewable energy, Intended Nationally Determined Contribution, Sustainable Development Goals, decentralised energy solutions.

\section{INTRODUCTION}

In the context of the EU Erasmus Plus Program "Social Inclusion and Energy Management for Informal Urban Settlements (SES)", running for three years until 2019, with Ethiopia as the African partner, social and environmental aspects for the sustainable development of informal settlements (slums) are the main focus. A holistic approach in Ethiopian universities' existing academic programs for future architects, urban developers and energy managers is developed, and additionally responsible personnel at local authorities will be trained. Coordinated by Danube University Krems the project aims at:

- Support the production of Open Educational Resources by jointly developing city résumés, indigenous case studies and course descriptions, following MIT's Open Courseware model.

- Increase the relevance of architecture and planning studies by introducing inter- and transdisciplinary topics like social inclusion, sustainable housing, energy management, participatory mapping and environmental risk assessment.

- Strengthen the relations between universities in Ethiopia and their wider socioeconomic environment by arranging information, consultation and feedback mechanisms with different social actors during case studies, by providing external trainings to stakeholders, by organising local dissemination workshops and national conferences, and by sharing Open Educational Resources and complementary materials via a website. 
These results will sharpen the profile of universities and their responsiveness to societal needs, improve the employability of graduates as well as the networking between local stakeholders and intensify contacts between Ethiopia and Europe.

The current situations of informal settlements and of energy supply and demand in Ethiopia are, as one of the key aspects of the project SES, the focus of this paper.

\section{ETHIOPIA}

Ethiopia is located in the north-east of Africa, in the Horn of Africa (Fig. 1). The country has never been colonised, apart from a five-year occupation by Italy. Ethiopia is a founder member of the United Nations and a base for many International and African organisations. The major languages are Amharic, Oromo, Tigrinya and Somali, the major religions are Christianity and Islam. The life expectancy is 67 for women and 63 for men, the currency is Birr [1].

The country with its very rich cultural heritage is classified as a least developed country (LDC) by the United Nations. LDCs mean low-income countries facing structural impediments to sustainable development, highly vulnerable to economic and environmental shocks and with low levels of human assets.

Challenges of the country are still poverty, education, gender, maternal mortality, nutrition etc., but also the consequences of climate change. It is estimated that around $40 \%$ of the Ethiopian people live in poverty. In 2015 the ratio of graduates from primary school was $54.4 \%$. For the same year, the access rate to clean water is indicated with $57.3 \%$, the access rate to sanitary facilities just with $28 \%$. Agriculture contributed with a share of $41.9 \%$ to the GDP in 2014. In 2015 nearly $12 \%$ of the population had access to internet [2].

The annual economic growth is currently around $8 \%$. The industrial sector has still a relatively small contribution to the GDP with $20.6 \%$ in $2015 / 16$, the sector agriculture, forestry, fishing and hunting still $37.2 \%$. The main export goods are coffee, tea, cacao with $30 \%$ in 2016 , or gold with $10 \%$ of the total exports in $2015 / 16$. In the same year the good imports exceeded the good exports more than six times.

Social protection in Africa's strategy for reducing poverty and forcing a sustainable development is emphasised in the African Union's Agenda 2063. Rapid population growth and urbanisation, poverty and climate change are big challenges for the sub-Saharan Africa, including Ethiopia.

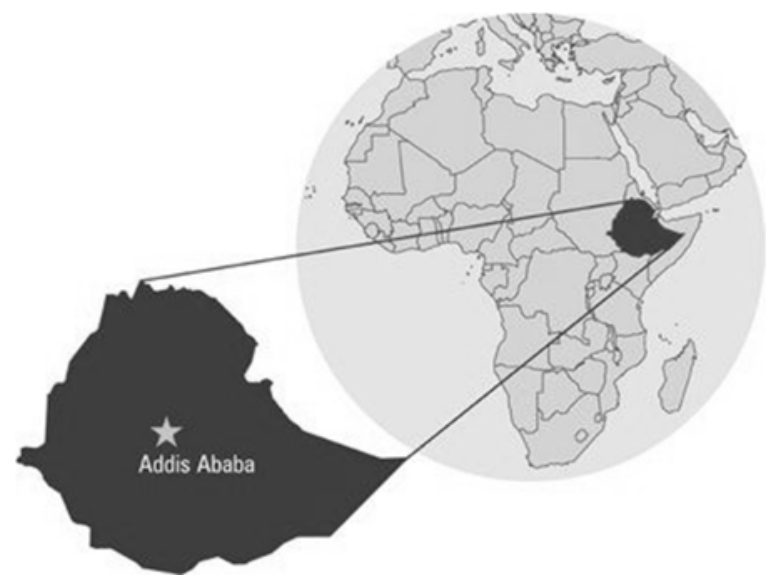

Figure 1: Geographical position of Ethiopia, Africa [2]. 
The policy of the Ethiopian government focuses on the reduction of poverty and the expansion of basic services like water and sanitation, refuse and waste removal, as well as access to electricity and energy [3].

Ethiopia has with around 100 million individuals the second highest population in Africa. Currently the urbanisation rate is with $20 \%$ relatively low, so urbanisation is a big challenge in Ethiopia. The population growth of Ethiopia is estimated to reach nearly 190 million of individuals in 2050. The urbanisation rate will be around 37\%, nearly double than in 2015 .

The poverty rate is often seen more as a rural problem, and that urbanisation in Africa can be important for reducing poverty. But in Ethiopia the urban poverty rate is indicated with around $27 \%$, nearly reaching the rural poverty rate of $30 \%$, which challenges this hypothesis [4].

\section{INFORMAL SETTLEMENTS}

Informal settlements are characterised by poor quality of services, housing and infrastructure, often completely without energy supply. Synonymous for informal settlements are e.g. squatter, slum, irregular, unplanned. In Ethiopia, they are also called illegal settlements or "moon-shine houses" (built on squatted land during one night). There is no clear definition of informal settlements, the UN Habitat, for example, categorises informal settlements as follows [5]: "1) inhabitants have no security of tenure vis-à-vis the land or dwellings they inhabit, with modalities ranging from squatting to informal rental housing, 2) the neighbourhoods usually lack, or are cut off from, basic services and city infrastructure and 3 ) the housing may not comply with current planning and building regulations, and is often situated in geographically and environmentally hazardous areas".

In sub-Saharan Africa 55\% of the urban population live in informal settlements (slums), half of slum-dwellers live in poverty. Living under such circumstances means a lot of social and ecological problems for the inhabitants and the society. Informal settlement dwellers benefit much less from the opportunities of an urban environment.

In Ethiopia, and its capital Addis Ababa, $80 \%$ of the urban population live in slums with an urbanisation rate of $8 \%$ per year. Nearly $25 \%$ of the inhabitants of the capital of Ethiopia have no access to sanitary facilities. Numbers for Ethiopia say that $42 \%$ of the habitants are without toilets, around $40 \%$ of the homes have just one room, and $39 \%$ are without a kitchen [6], [7].

Fig. 2 shows informal settlements in Ethiopia during site visits of European and African members of the project SES in Addis Ababa (with electrification) and in Gondar (without electrification or any infrastructure) in 2017.
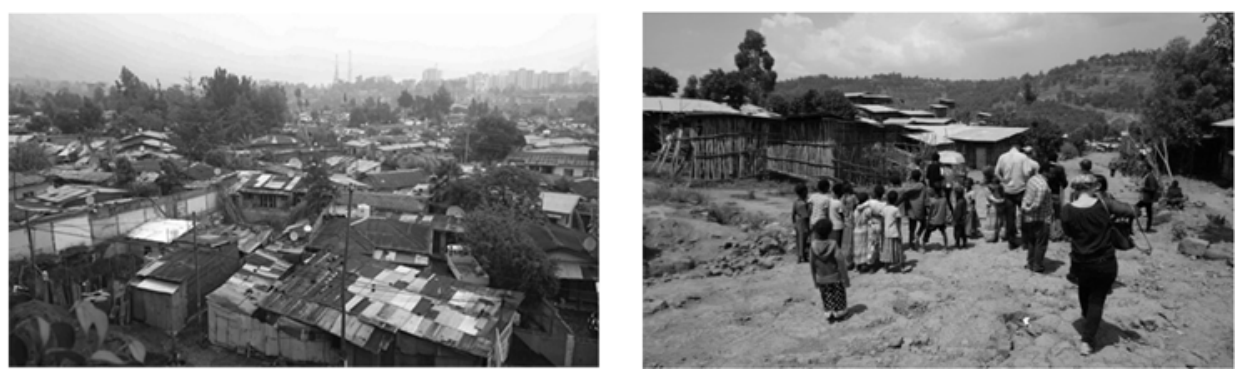

Figure 2: Informal settlements in Addis Ababa and Gondar. (Source: (C) Hoeltl.) 

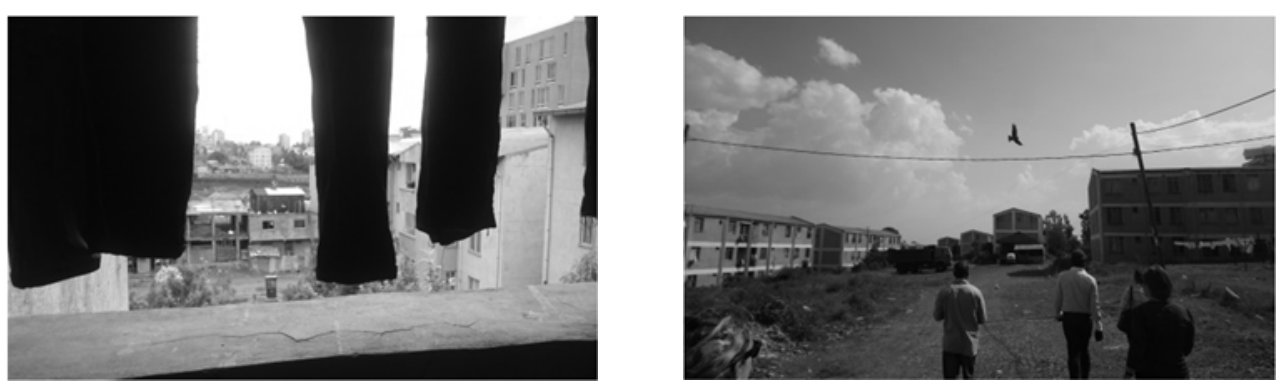

Figure 3: Condominiums in Addis Ababa and Gondar. (Source: (C) Hoeltl.)

The photos in Fig. 3 provide an insight into condominiums during the same site visits in the same cities of Ethiopia. For improving the situation of people living in urban informal settlements, the cities of Ethiopia provide so-called "condominium housing programmes". Within these programmes multi-storied housing units for low and middle income households are built. It is criticised that these programmes and buildings take folkways too less into account and are not affordable for the poorest [8].

\section{ENERGY AND $\mathrm{CO}_{2}$ EMISSIONS IN ETHIOPIA}

Energy access is a basic need and essential not only for the opportunities of the individuals, but also for the national economic development, especially for Least Developed Countries.

\subsection{National and international framework}

Ethiopia adopted a Climate Resilient and Green Economy (CRGE) strategy aiming to become a carbon-neutral and climate change resilient green economy [9].

The Ethiopian's second Growth and Transformation Plans (GTP II) 2015/16-2019/20 are including the CRGE strategy as the important pillar building a climate resilient green economy with the effect of corresponding legal, policy and institutional frameworks at the federal, regional and district levels, e.g. a ten-year forest sector development programme. However, Ethiopia faces big challenges from climate change consequences [10].

Affecting temperature as well as rainfall levels, Africa is considered as the most vulnerable continent to climate change. The temperature is predicted to increase up to $2.1^{\circ} \mathrm{C}$ by 2050 , and rainfall to decrease dramatically in Ethiopia.

As a member of the United Nations, Ethiopia has accepted and supports the 2030 Agenda for Sustainable Development and the Sustainable Development Goals (SDGs) with national commitments. In the Voluntary National Review (VNR) 2017, Ethiopia refers to a number of consultations ensuring the involvement of all relevant stakeholders, the government, the private sector, the civil society, NGO, business etc. The Ethiopian government indicates three main approaches: 1) Review of existing government laws and development policies. 2) Organising and analysing statistical data and/or information. 3) Conducting inclusive national consultations on the VNR draft 2017 [11].

Ethiopia has integrated the SDGs, shown in Fig. 4, in the national Growth and Transformation Plan (GTPII). In this context a main goals of Ethiopia is "Eradicating Poverty and Promoting Prosperity" and on the six sets of sustainable development goals for the 2017 in-depth review of SDGs, which include Goals I, 2, 3, 5, 9 and 14. 


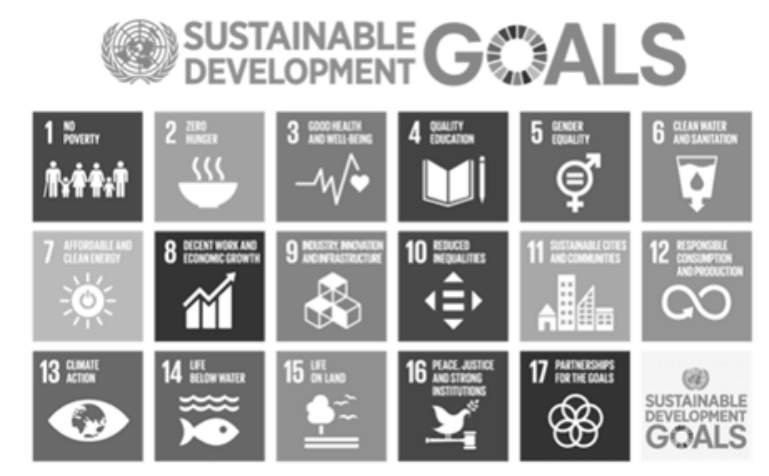

Figure 4: The 17 UN Sustainable Development Goals [12].

Regarding the project SES, SDG 7 "Affordable and Clean Energy" is an issue, too. The aim of this goal is to "ensure access to affordable, reliable, sustainable and modern energy for all" [12].

Ethiopia also ratified the Paris Climate Agreement in March 2017, the international agreement of the United Nations Framework Convention on Climate Change, aiming to limiting global warming to well below $2^{\circ} \mathrm{C}$ [13]. The agreement is especially important for least developed countries and countries which are particularly vulnerable to the adverse effects of climate change. It fosters industrial countries to fund least developed countries and support the transfer of technology. Efficient access to financial resources shall be ensured in the context of the national climate strategies and plans.

In the context of the Paris Agreement the countries are obligated to provide a Nationally Determined Contribution (NDC) 2015 [14]. Ethiopia submitted its NDC in March 2017. An important aim is the reduction of the vulnerability of the country and of its people to the adverse effects of climate change. The NDC intends to force modern and energy efficient technologies in transport, industry and in the building sectors, and to develop and implement climate change compatible building/construction codes for buildings. Fig. 5 shows that Ethiopia wants to reduce its greenhouse gas emissions on the basis of the protected businessas-usual emissions by $64 \%$ in 2030 , and in the long term to become carbon-neutral.

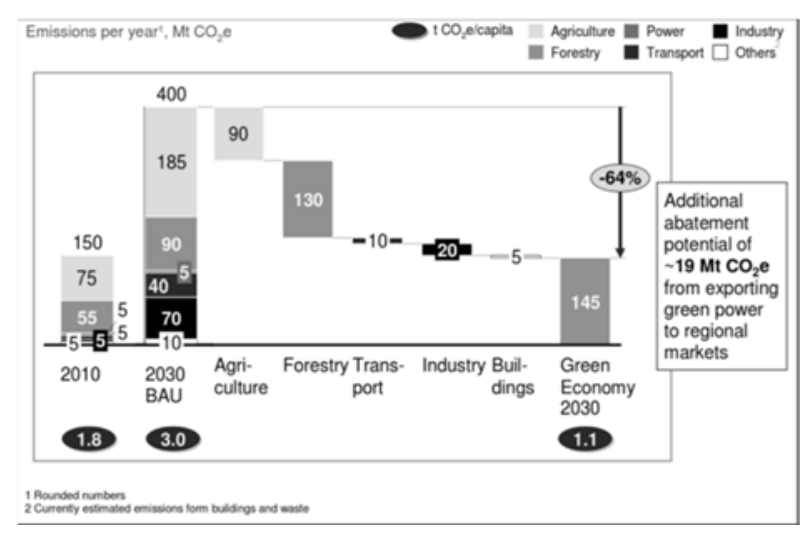

Figure 5: Intended greenhouse gas emissions reduction of Ethiopia until 2030 [14]. 


\subsection{Energy situation in Ethiopia}

Fig. 6 shows the development of energy production, net energy imports, total primary energy supply (TPES), electricity consumption and the $\mathrm{CO}_{2}$ emissions in Ethiopia between 2000 and 2015. The average annual growth rates were respectively (in sequence) $2.86 \%, 8.54 \%$, $3.09 \%, 12.38 \%$ (electricity consumption), and $8.4 \% \mathrm{CO}_{2}$ emissions. An extrapolation of these growth rates until 2030 will end up e.g. in electricity consumption 5.7 times higher than 2015 .

As we may see in Fig. 7 the primary energy supply is with $91.6 \%$ based mainly on biofuels or waste. One reason may be that transport and industry are still on a very low level. The share of industry in total final energy consumption was 3\% in 2015, for comparison, in Austria it was $34 \%$, in China $58 \%$, and in the US $25 \%$. The share of transport in total final energy consumption in Ethiopia was $4 \%$ in 2015, in Austria 31\%, in China 16\%, in the US $42 \%$. However, the share of residential in total final energy consumption was $91 \%$ in Ehtiopia in 2015 , compared to $22 \%$ in Austria, $16 \%$ in China or $17 \%$ in the US.

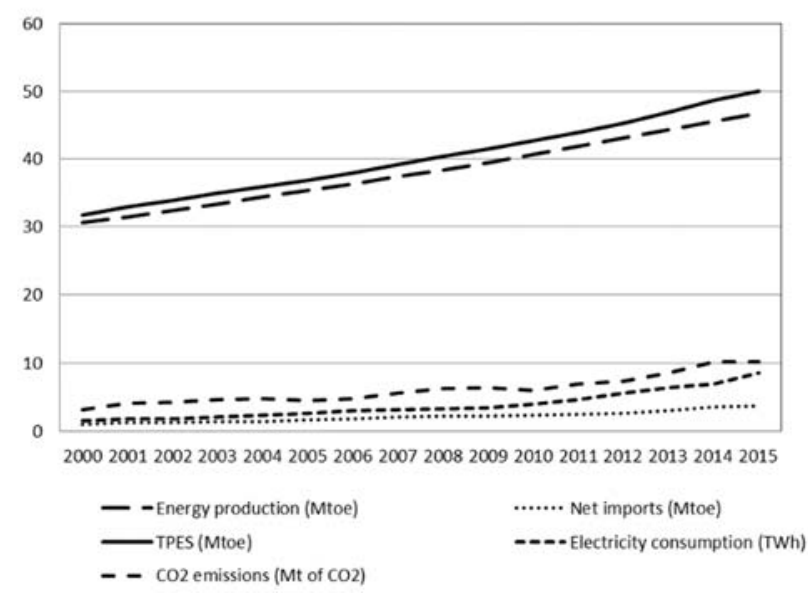

Figure 6: Ethiopian's energy data from 2000 until 2015 [15].

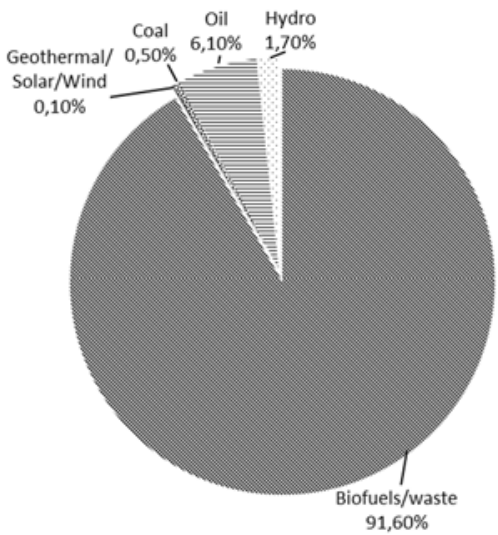

Figure 7: Ethiopian's share of total primary energy supply in 2015 [15]. 


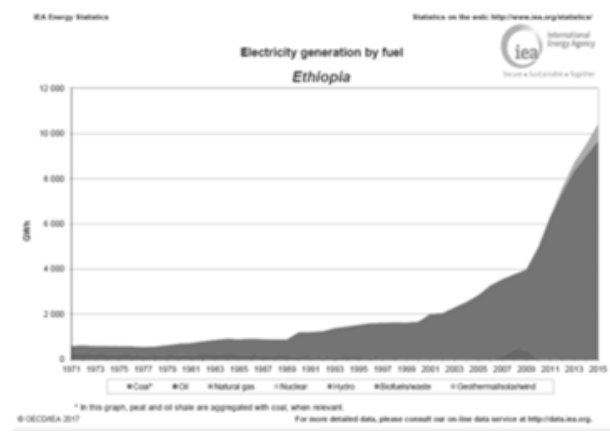

Figure 8: Ethiopians' electricity generation by fuel from 1971 until 2015 [15].

These numbers show clearly the very low level of Ethiopian's industrialisation. As Ethiopia of course strives to develop the country and the quality of live of the inhabitants, energy demand will increase tremendously. That may be in discrepancy and contradiction with the above mentioned aims of Ethiopia to reduce its greenhouse gas emissions by $64 \%$ until 2030 and may challenge the LDCs' demand for reducing the $\mathrm{CO}_{2}$ emissions.

Currently, Ethiopia is still able to produce electricity demand mainly by renewable resources, hydro power and with a small part geothermal/wind/solar power, see Fig. 8 .

However, according to data of the world bank [1], in 2014 in the rural areas of Ethiopia just $12.2 \%$ of the inhabitants had access to electricity, in the urban areas $91 \%$. Furthermore, comparing the electricity consumption per capita of Ethiopia in 2015 with that of an industrial country, e.g. Austria, shows the major difference and in a certain way the least development of the African country by that. Fig. 9 indicates the electricity consumption for Ethiopia with $0.09 \mathrm{MWh} /$ capita, for Spain with 5.48 MWh/capita, and for Austria with $8.35 \mathrm{MWh} /$ capita. So in 2015, in Austria the electricity consumption per capita was 92 times higher than in Ethiopia. Of course it shouldn't be an aim for Ethiopia to exceed the electricity consumption/capita of Austria, because in Austria energy inefficiency is still an issue. But the relationship of a certain minimum standard of electricity consumption and well-being and quality of life is evident, and implicates the dimension of (maybe required) forthcoming energy and electricity needs in Ethiopia.

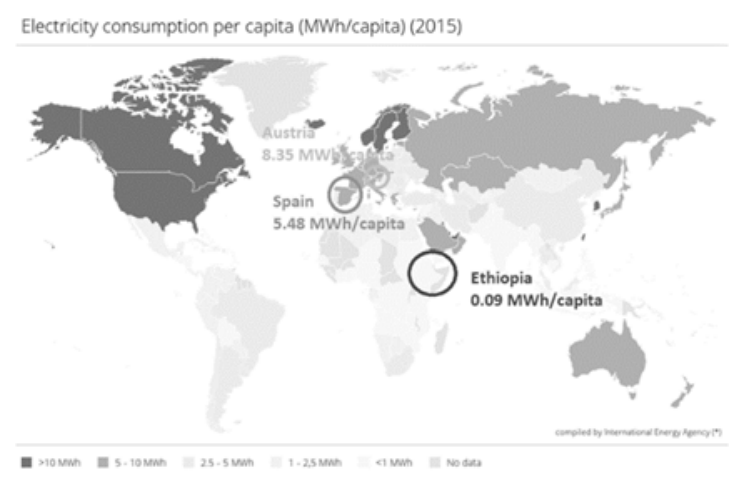

Figure 9: Electricity consumption per capita in MWh of Ethiopia, Spain and Austria in 2015 [15]. 


\subsection{Carbon dioxide emissions in Ethiopia}

Compared to the industrialised countries the carbon dioxide emissions per capita in Ethiopia can be seen as insignificant. Worldwide, China emits most with 9,000 Mt in 2015, followed by the United States with 5,000 Mt and India with 2,100 Mt $\mathrm{CO}_{2}$. Fig. 10 shows the numbers for Ethiopia (10.2 Mt), Spain (247.0 Mt) and Austria (62.1 Mt).

Considering the $\mathrm{CO}_{2}$ emissions/capita (Fig. 11), the difference in $\mathrm{CO}_{2}$ emissions and thereby the contributions of the individual countries to the anthropogenic climate change become much more evident. From that point of view, the United States were the biggest $\mathrm{CO}_{2}$ emitter with 15.56 tons/capita in 2016, one American emitting approximately twice than an Austrian or a Chinese. An Ethiopian emitted 0.1-ton $\mathrm{CO}_{2} /$ capita. So, one American emitted 155 times more $\mathrm{CO}_{2}$ than an Ethiopian, an Austrian still 85 times more and an average citizen of our world 48 times more.

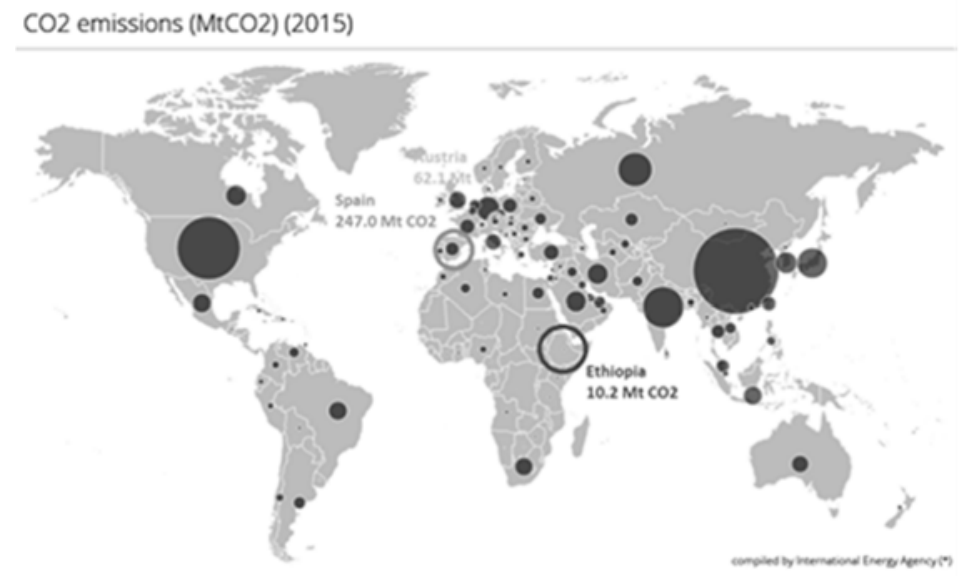

Figure 10: $\mathrm{CO}_{2}$ emissions in Mt of Ethiopia, Spain and Austria in 2015 [15].

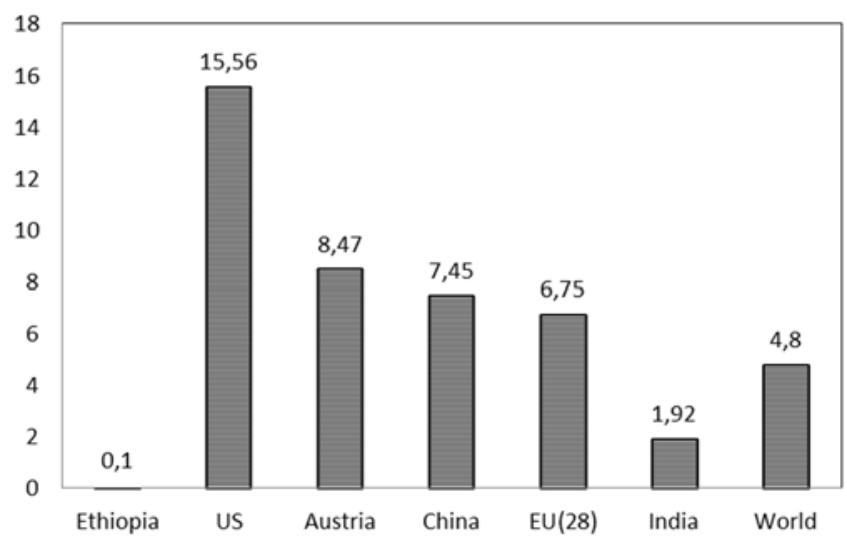

Figure 11: $\mathrm{CO}_{2}$ emissions in tons/capita in Ethiopia, the US, Austria, China, the $\mathrm{EU}(28)$, India, and worldwide in 2016 [16]. 


\subsection{Best practice for informal settlements in Ethiopia}

Beside the requirement of a detailed, holistic and long-term energy and environmental concept on the national level, Ethiopia may benefit from a wide range of different and decentralised solutions. A couple of such approaches, partly already adapted in Ethiopia, are shown here.

Under the title "a social business making biogas accessible", a project provides on the one hand small business opportunities for local people and on the other hand energy for cooking in informal settlements. This is a best practice from different perspectives like innovation, ecology, socio-economy, entrepreneurship and technique. The idea of producing biogas from e.g. cow dung of course already exists for decades in Africa, too. The innovation is the biogas backpack, which allows the people in informal settlements to transport the biogas to their place of residence. Fig. 12 shows a woman in Addis Ababa carrying biogas for cooking to her home.

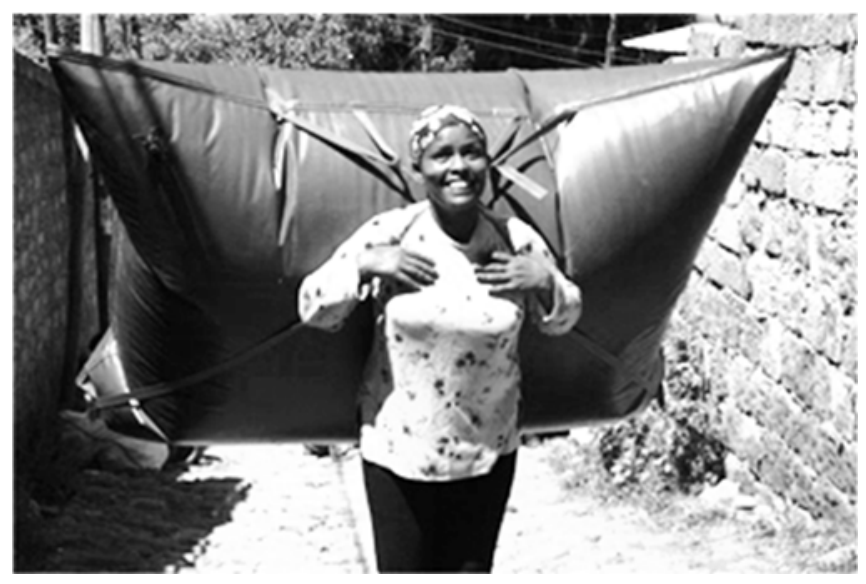

Figure 12: Salome Zeresulos carrying a biogas backpack in Addis Ababa [17].

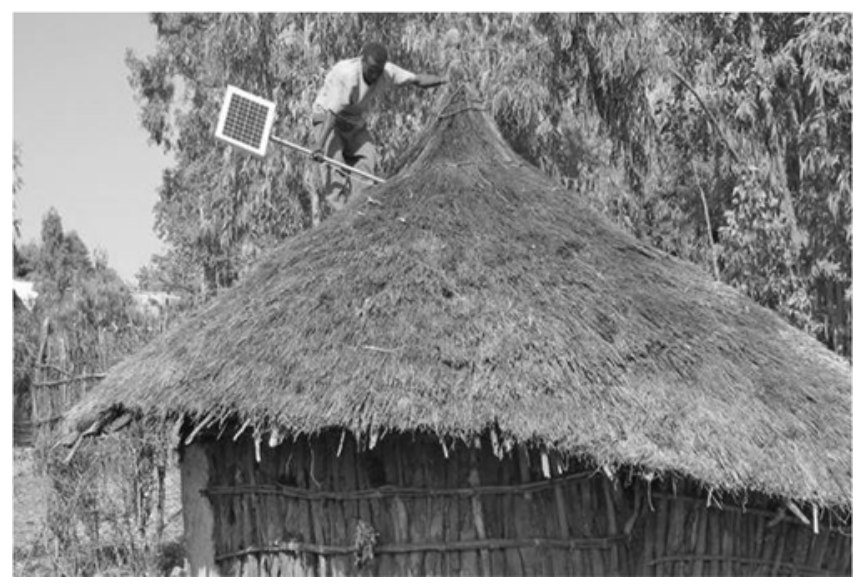

Figure 13: Decentralised solar power solution [18]. 
Different decentralised solar power solutions of course are already implemented, as well, but in a very small extend given the potential of solar energy in Ethiopia. The Solar Energy Foundation e.g. supports decentralised solution in (least) developed countries, also in Ethiopia, emphasising the importance of access to electricity for education, clean water, improved health care and poverty alleviation.

There are a large number of further solution approaches on a decentralised level, like e.g. batch-type homemade solar water heaters, with the idea to use mainly old materials for the water heater and a specific design for a more efficient use.

\section{CONCLUSION}

Currently Ethiopia has with $20 \%$ a relatively low degree of urbanization, and by that a high annual growth rate of $8 \%$ in this regard. Hence, the country faces huge challenges from an economical, ecological and social point of view.

Taking a look at the energy situation, the case of Ethiopia shows that least developed countries face an enormous discrepancy concerning environmental protection, international agreements and sustainable development. On the one hand Ethiopia is still confronted with a very low rate of access to electrification, and by that also with a very low developed economy, on the other hand the country is forced to reduce $\mathrm{CO}_{2}$ emissions by international agreements. Very ambitiously, Ethiopia aims to become a carbon-neutral country by 2030. Of course, reaching that goal should be strived, but by the fact that Ethiopia will need high energy increases for the development of the country and for increasing quality of life, support of the industrialised countries regarding funding and technology transfer, as an obligation of the Paris Agreement, has to be taken very seriously.

\section{ACKNOWLEDGEMENT}

The SES project is funded by the Erasmus + program of the European Union. The European Commission support for the production of this publication does not constitute an endorsement of the contents which reflects the views only of the authors, and the Commission cannot be held responsible for any use which may be made of the information contained therein.

\section{REFERENCES}

[1] World Bank, Ethiopia, 2018. www.worldbank.org/en/country/ethiopia/overview.

[2] IOCC, Improving Health and Economic Stability for Families, 2018. https://www.iocc.org/where-we-work/ethiopia.

[3] AfDB, OECD, UNDP, Ethiopia 2017, African Economic Outlook, 2017.

[4] OECD Social Protection in East Africa: Harnessing the Future, OECD Publishing: Paris, 2017. http://dx.doi.org/10.1787/9789264274228-en.

[5] UN Habitat: Informal Settlements. Habitat III Issue Papers 22, New York, 31 May 2015.

[6] Habitat for Humanity, Slum Housing in Ethiopia. A Master Plan to Modernise? 2018. https://www.habitatforhumanity.org.uk/blog/2017/09/doomed-fail-slum-housingethiopia/.

[7] Dubbale, D.A., Tsutsumi, J. \& Bendewald, M.J., Urban environmental challenges in developing cities: the case of Ethiopian capital Addis Ababa. International Journal of Environmental, Chemical, Ecological, Geological and Geophysical Engineering, 4(6), 2010.

[8] Achamyeleh Gashu A., Informal settlements in the peri-urban areas of Bahir Dar, Ethiopia: An institutional analysis. Habitat International, 43, pp. 90-97, 2014. 
[9] Federal Democratic Republic of Ethiopia, Ethiopia's Climate-Resilient Green Economy. Green Economy Strategy, 2011.

[10] National Planning Commission, Growth and Transformation Plan II (GTP II) (2015/16-2019/20), Addis Ababa, 2016.

[11] United Nations Ethiopia, Voluntary National Review, 2017.

https://sustainabledevelopment.un.org/memberstates/ethiopia.

[12] United Nations, Sustainable Development Goals, 2018. http://www.un.org/ sustainabledevelopment/news/communications-material/.

[13] United Nations, Paris Agreement, New York, 2015.

[14] Federal Democratic Republic of Ethiopia, Intended Nationally Determined Contribution (INDC) of the Federal Democratic Republic of Ethiopia, Addis Ababa, 2017.

[15] International Energy Agency, Statistics, Ethiopia, 2018. https://www.iea.org/statistics/ statisticssearch/report/? country=ETHIOPIA\&product=oil\&year=2015.

[16] WOK, Länderprofil Äthiopien, 2018. https://wko.at/statistik/laenderprofile/lpaethiopien.pdf.

[17] (B)energy, A Social Business Making Biogas Accessible, 2018. http://www.benrg.com/b-home/.

[18] Solar Energy Foundation, We switch the light on, 2018. http://solar-energyfoundation.org/. 